\title{
Individualism, Community, and the Law: A Review Essay
}

Lawrence Rosen $\dagger$

The Lonely Crowd. David Riesman with Nathan Glazer and Reuel Denney. Yale University Press, New Haven, Connecticut, 1950 (abridged ed. 1969). Pp. Ixii, 315. $\$ 10.95$ (paper).

Habits of the Heart. Robert N. Bellah, Richard Madsen, William M. Sullivan, Ann Swidler, and Steven M. Tipton. Harper and Row, New York, 1985. Pp. xii, 355. $\$ 8.95$ (paper).

When Alexis de Tocqueville came to write his famous study, Democracy in America, he used the recently coined term "individualism" to refer to the social and political climate that conduces each member of the polity to concentrate on his or her own small sphere of well-being to the detriment of any broader commitment. "Individualism," he wrote, is not the same as "egoism"-_"a passionate and exaggerated love of self which leads a man to think of all things in terms of himself and to prefer himself to all"-but is, instead, "a calm and considered feeling which disposes each citizen to isolate himself from the mass of his fellows and withdraw into the circle of family and friends; with this little society formed to his taste, he gladly leaves the greater society to look after itself."' Although Americans did not have to attain democracy through revolution against an entrenched aristocracy, they have had to face the threat that equality might lead to the rise of despots who find opportunity in the individual's indifference to public affairs and danger in anything that draws people together in a common bond. ${ }^{2}$ To counter this tendency, Tocqueville believed, the founders

$\uparrow$ Professor of Anthropology, Princeton University; Adjunct Professor of Law, Columbia University.

1 Alexis de Tocqueville, Democracy in America 506 (Anchor Books ed. 1969).

2 Id. at 510 ("Equality puts men side by side without a common link to hold them firm. Despotism raises barriers to keep them apart. It disposes them not to think of their fellows and turns indifference into a sort of public virtue. Despotism, dangerous at all times, is therefore particularly to be feared in ages of democracy."). 